\title{
Factors Contributing to Some Cultural Dimensions of Saudi Arabia
}

\author{
Dr. Naif Daifullah Z Alsulami \\ Umm Al-Qura University \\ Mecca, Saudi Arabia
}

\begin{abstract}
The purpose of this article is to develop a better understanding about how some factors have shaped some cultural dimensions of Saudi Arabia. Concerning the dearth of the literature written in English about this topic, this article will contribute by filling this gap in the literature. This article shows that there five main factors have played a big role in shaping many aspects of Saudi culture. These factors include religious, politics, economic, social and educational factors.
\end{abstract}

\section{Overview}

Saudi Arabia was established in 1932 by King Abdul Aziz Ibn Saud. It is located in the heart of the Middle East, and South Western part of Asia. It is the largest country in the region (See figure 1 below). It occupies about 865,000 square miles, approximately 80 per cent of the Arabian Peninsula (Long, 2010). Although the total population is around 32 million, it has a very young population. According to the latest official statistics, 79 per cent of the Saudi population is under 40, and 36 per cent of the population is younger than 15 (General Authority for Statistics, 2017). Thus, Saudi Arabia is classified as a young society which is characterised by the qualities of youth, desire for change, and facing challenges. This also reflects a change in the way Saudi Arabia is governed. For the first time in Saudi history, a 32year-old Crown Prince - Muhammad bin Salman - was appointed in June 2017. He stated this is the time for change: I am a young man within this young society looking for change, we have to convince people to change, and we have all the qualifications and the resources to be one of the developed countries. In fact, this new policy reflects the keenness of the political leadership to change the society in order to be better and to eliminate the cultural defects that existed in Saudi Arabia, which will become clear to the reader.

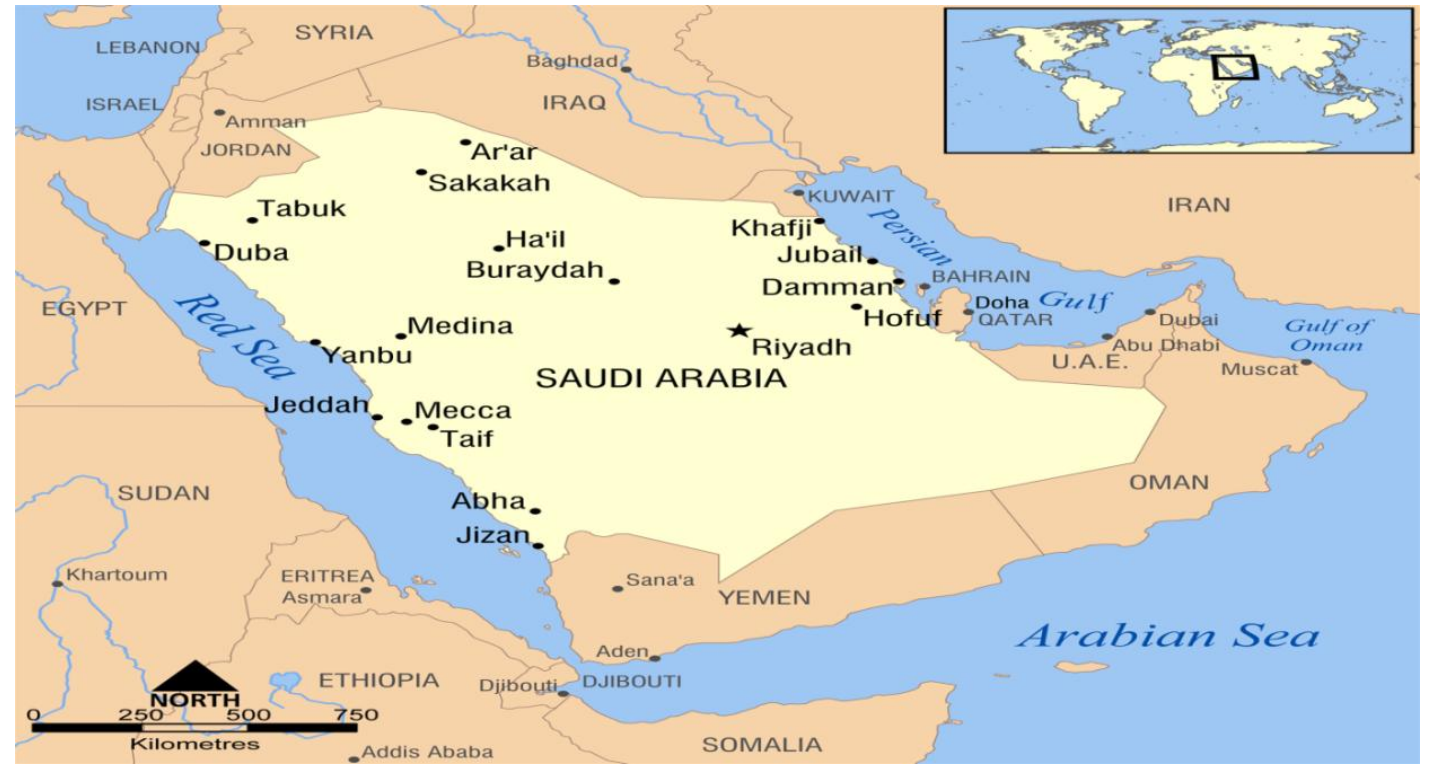

Figure 1: Map of Saudi Arabia

The country has a uniqueculture, unlike most Islamic countries that tend to be secular and remove the religion from the politics, Saudi Arabia introduced itself as a religious country. As stated in the first article of the basic law of governance (constitution) of the country: Saudi Arabia is an Islamic Arab state with full sovereignty, its religion is Islam and its constitution is the Book of Allah (the Holy Quran), and the Sunnah (way of life) of his prophet Muhammad (Peace be upon him) and its language is Arabic (Ministry of Education in Saudi Arabia, 2017). Therefore, the statistics showed that 100 per cent of the Saudi population is Muslim (General Authority for Statistics, 2017). 
According to Denman and Hilal (2011) 'the Islamic religion is considered as much a part of the Saudi identity' (p. 304). Consequently, in a country which could be considered as a religion-based society, there are huge impacts of Islamic laws - or in other words, the interpretations of Islamic law - in shaping and forming the Saudi national identity, as will be discussed in detail later.

\section{Historical background}

A certain amount of the historical context is nevertheless necessary in order to understand how and why certain factors have formed certain dimensions of Saudi culture, which might not exist in other cultures. In fact, highlighting some events about the beginning of the establishment of the country is important for developing a better understanding about the current Saudi culture and society because it will justify the main idea behind establishing this new country in the Arab peninsula. It also helps us understand why Sunni Muslim religion and the royal regime have the ultimate power in shaping the Saudi society.

Saudi Arabia did not experience direct colonisation; however, the holy sites (Mecca and Medina) were under the control of the Ottoman Empire. Other parts of the Arabian Peninsula were traditionally ruled by tribal leaders (Alothaimeen, 1997). According to Al-Abdulkaream (2012), Islam was the religion of the people in the Arab Peninsula. Nevertheless, because of the illiteracy at that time, most of the people were far from knowing the correct teachings of Islam. Myths were spread and worshiping ancestors' graves was common among people. However, a man called Muhammed bin Abdulwahhab (born in 1703 in Aloiaynh a town in the middle of the peninsula), was not satisfied with what people were doing, as they did not practice the correct path of Islam. He was sponsored by his father to travel to India, Hijaz, Iraq and Al Ahsa to meet some Muslim scholars and to learn from them. After spending some years abroad, he came back to his home with the intention to foster change. Interestingly, the re-entry of Muhammad bin Abdulwahhab was one of the first re-entries that influenced the history of the region.

Muhammad bin Abdulwahhab allied with a strong tribal leader -Muhammad bin Saud- in 1744 to establish an Islamic State in the Arabian Peninsula based on Muhammad bin Abdulwahhab's interpretations of the religion, which was mixture of his experiences of studying abroad and his environmental culture. They agreed that Muhammad bin Saud and his descendants are the political leaders of this new state (Alothaimeen, 1997). The new state experienced historical conditions that caused it to fall twice until the current re-establishment of the state by King Abdul Aziz bin Saud -one of the descendants of Muhammad bin Saud - the founder of the first Saudi state-. The Kingdom of Saudi Arabia presents itself as an extension of the old alliance between Muhammad bin Abdulwahhab and Muhammad bin Saud, as clearly mentioned in the basic law of governance (constitution): Sheikh Muhammad bin Abdulwahhab called for reformism, on which the Saudi state was based, which is the cornerstone of governance. This call was based on the establishment of the laws of Islam and the promotion of virtue and prevention of vice and the application of the principles of Islamic law. Therefore, it derives its principles from the correct Islamic principles that prevailed in the previous eras of Islam (Ministry of Education in Saudi Arabia, 2017).

\section{Factors contributing to cultural dimensions of Saudi Arabia}

As a country that was established just 85 years ago (Al-Rasheed, 2010), there are five main factors that have contributed to and formulated the cultural dimensions of Saudi Arabia: religious, politics, economic, social and educational factors. In fact, the religious and political factors are the main and the most important factors, especially at the beginning of the establishment of Saudi Arabia, as briefly mentioned in the previous section. The other three factors (economic, social and educational) are also important in shaping and re-shaping the cultural dimensions of Saudi Arabia. However, they could be considered as secondary factors compared to the first two. Sometimes several factors merge in forming one phenomenon, such as gender segregation, as in preventing females from driving cars.

\subsection{Religious factors}

As explained earlier, the religious factors are the most important factors in shaping the cultural dimensions of Saudi Arabia, but more detail explains how and why Islam has a huge impact on Saudi culture.

Islam is therefore one of the most important factors that has shaped Saudi culture for historical, geographical and governmental reasons. Historically, the Arab peninsula is considered as the source of Islamic faith from the era of the prophets Abraham and his son Ishmael (known as the father of Arabs), who built the holy building in Mecca called House of God (Kaaba) for the monotheistic faith and worshipping one God. Within the Islamic literature, Judaism, Christianity and Islam share the same source.

Therefore, Muslims believed that all prophets, including Moses and Jesus, visited this building and did pilgrimage. Moreover, the last prophet of God, Muhammad, started his call to Islam from the Arab Peninsula and stated at the end of his life; "Get out the polytheists from the Arabian Peninsula" (Albukhari, 2001), and another statement of the prophet Muhammad is that 'there should not be two religions in the Arab Peninsula, only Islam' (Ahmad, 1995). 
This literature is part of Islamic faith, therefore, most particularly of the Arabian Peninsula people, and Saudis believe that this country should be only for Muslims. Consequently, statistics showed that 100 per cent of the Saudi population are Muslims. Hence, historical Islamic valuing of the holy sites in Saudi Arabia provided this country with particular religious significance and privacy, compared to other Islamic countries.

Geographically, the Arabian Peninsula remained the country of the Islamic caliphate for nearly 50 years at the beginning of Islamic history (610 AD), before it had been changed to Kofa city in Iraq. Then, after the transferral of the Islamic caliphate capital to the city to Kofa, the Arabian Peninsula was no longer united under one political regime, rather it was separated into different provinces following different regimes until it was finally controlled by Ottoman Empire (Ibn Sonitan, 2008). However, after establishing Saudi Arabia, Muslims looked at this state retrospectively and thought that it should represent Islamic teachings. Saudi Arabia is therefore considered the birthplace of Islam, containing the holy sites in Mecca and Madinah. Moreover, during their daily five prayer sessions, all Muslims perform their prayers towards the direction of Mecca in Saudi Arabia. Thus, the significance of Saudi geography as the source of Islam has provided religious factors with the power of shaping the Saudi culture.

Governmentally, King Abdul Aziz united the country by the word of God, saying that he will apply Islamic law and spread Islamic teachings to this state. He used some Islamic symbols to represent the Islamic identity of the country, such as the sword and the words written on the Saudi flag. The sword refers to the tool that has been used by the Prophet Muhammad and the previous Muslims to spread the religion outside the Arabian Peninsula. The words written on the flag in Arabic can be translated as (There is no God but Allah, and Muhammad is his Messenger). Abdul Aziz was a religious man and his close consultants were from amongst prestigious Islamic scholars. In fact, the role of Saudi Islamic scholars was evident since the establishment of the first Saudi state (1744-1818), the second Saudi state (18241891) and the third Saudi state, known as Saudi Arabia (1932-present). Their roles have been played in various ways, including convincing people that the rulers would establish a new Islamic country and helping people improve their lives. Consequently, some cities, such as Mecca and Jeddah, joined the new country peacefully (Alkhidr, 2011). In appreciation of the role of those scholars and in the affirmation of the religious identity of the country, in most decisions the King consults the opinions of Saudi religious scholars in a committee known as the Council of Senior Scholars, chosen by the King himself. One of the responsibilities of this council is to give an opinion on what is referred to it by the king for the purpose of his research and the formation of opinions based on religious evidence, and to give recommendations in religious cases concerning the determination of general provisions to guide the king (Council of Senior Scholars in Saudi Arabia, 2017).

Based on their interpretations of Islam, these scholars, with the agreement of the decision makers, have shaped some of the dimensions of Saudi culture, such as gender segregation and censorship of some social activities, including banning cinema and preventing women from driving cars (Alhazmi, 2015). These interpretations known globally as Wahhabism. Saudis do not like the name (Wahhabism), claiming that their interpretations are based on previous Muslims scholars, particularly Ibn Taimyah (1263-1328) and his student, Ibn AlQayyam (1292-1349), who lived and died in Syria. They did not contribute anything new. However, whether they approve or not, this name is becoming widespread in many resources, including in Western and Arabic resources and does not intrinsically contain any insult to Saudi people.

Although most of the Wahhabis' interpretations are taken from the above-mentioned scholars, the Saudi cultural environment (such as living in deserts, and living in a closed society, as in the previous century) has negatively affected the construction of most of Saudi scholars' ideas. This impact can be seen, for instance, concerning issues on living and travelling to non-Muslim countries, as in famous fatwa of the ex-president of senior scholars' council Sheikh Abdul Aziz bin baz (died in 1999): he warned the government against sending Saudis to study abroad in non-Muslim countries except in emergencies (knowledge that does not exist in Islamic countries). He advised the government that it should establish courses to prepare those students religiously for studying abroad, and those students should be supervised while studying abroad (Bin baz, 2017). Such views or 'Fatwa'are prevalent in Saudi Arabia. Therefore, many distinguished Saudis have left to travel to study abroad. In fact, Fatwa literature shows that Saudi religious leaders are suspicious of anything coming from the West and consider it as religiously prohibited, seeing what happened when Western inventions came to Saudi Arabia (such as cars, telephone, satellite and camera), as all these were considered religiously prohibited (Alarfaj, 2011).

Observers of Saudi culture can clearly see the important role of Fatwa-making by Saudi religious scholars in forming many dimensions of Saudi society. Fatwa is defined as an informal decision made by religious scholars telling the people what is permitted and legal in their religious teachings and practices and what is not. The decisions are based on the scholars' understandings and interpretations of the Holy Quran and the Prophet Muhammad's life. Most of Saudi's people respect those scholars and tend to ask them about what they do not know or understand in their religion. 
Therefore, Fatwa programs are quite common in Saudi media, either daily or weekly, where Saudi religious scholars are invited to respond to people's queries by phone calls. However, Alarfaj (2011) wrote a book analysing the Saudi scholars' opinions of Fatwa. Alarfaj (2011) argued that the Saudi religious scholars initially forbade 90 per cent of the modern material. Then, after many years, it became considered as normal. This point is very critical for understanding suspicious reactions from Saudi Islamic scholars toward new civilisations and societies.

Interestingly, some researchers reported that Saudi Arabia tended to be more open and engaged with the world in the late of sixties and seventies. Then, it allowed for TV broadcasting and opening cinemas despite of the opposition from some conservatives. 'Conservatives' refers to Saudi citizens who are more religious and are practising the religion regularly and they can be easily identified through having beards. They demonstrated and protested around the Ministry of Media, claiming that the government had become more liberal and had broken the Islamic laws based on their understandings (Alkhidr, 2011). However, the government continued this policy of engagement with the world and introducing other civilisations' materials until a major incident happened in Mecca known as the Johayman Incident, when a group of extremists in 1979 seized the Holy Mosque in Mecca and killed police officers and some people. Johayman and his group holed up inside the mosque claiming the Saudi government was not Muslim anymore and called for establishing a new Islamic state instead of the Al-Saud regime. For 17 days they remained holed up in the mosque until the government later arrested and killed them (Alhozaimi, 2011). The government realised after this incident that there is no benefit in provoking conservatives. Therefore, the government banned cinema, and after this incident, the government was very careful in dealing with any issues or controversial decisions which might attract people's outrage.

\subsection{Political factors}

On the political side, the regime in Saudi Arabia is considered as a monarchy, where the King manages the affairs of the state. He is also the Prime Minister, who has the ultimate power to make decisions regarding the state. The King must belong to the Al-Saud family and he chooses his crown prince, who will then succeed him as the king. The legalisation of the King is quoted and legitimised by the Holy Quran based on Wahhabis' interpretations ' $O$ you who believe! Obey Allah (God) and obey the Messenger (Muhammad), and those of you who are in authority' (The Holy Quran, An-Nisa, No. 59). The Wahhabisis interpreting those who have authority as politicians, especially the King and his Crown Prince. Therefore, Saudis highly respect the King and obey whatever decisions he makes. Even if they object, they cannot criticise decisions publicly. However, they can send secret advice to the King through a telegraph or e-mail. Royal decisions have the power to change the culture and lifestyle of the people. This can be clearly seen, for instance, in the determination of weekdays and weekends. Since the country was established, weekdays have been from Saturday to Wednesday, and weekends have been Thursday and Friday. This was practised until 2013 before the former king, Abdullah, decided to change weekdays to be Sunday - Thursday and weekends to be Friday and Saturday.

Al-Khidr (2011) stated that Saudi Arabia is a government-based society where the sources of knowledge that formed the consciousness of the generations are limited to government education, which is based on a traditional vision of religion, politics and economics, where only the government agendas and ideas can be taught to people. The implication of this view is that the similarities among Saudi people's perceptions and opinions toward many topics are evident, such as their belief that no one can rule the country better than Al-Saud family and the topics around interpretations of Islam, like the idea of gender-segregated environment for women working within the society. As a whole, until now Saudi Arabia is still politically stable compared to the surrounding countries, even during the Arab revolutions or the so-called 'Arab Spring' of 2011. In the Arab Spring in 2011 people from countries such as Tunisia, Libya, Egypt, Syria and Yemen demonstrated against their political regimes and called for changes because of the corruption among these governments and leaders. However, the Saudi Arabia regime was immune to these revolutions. Personally, I remember how most of the Saudi people were afraid of a change at that time, arguing that these revolutions were supported by foreign intelligence for their own agendas. To conclude, although the political system in Saudi Arabia differs from many democratic regimes in the world, the old religious-political alliances led to the stability of the Saudi regime and its smooth transition from a king to his crown prince.

\subsection{Economic factors}

The beginning of the establishment of Saudi Arabia was difficult and problematic as it was initially an area without natural resources. Previous generations of Saudis still remember the poverty situation they formerly lived in. My father told me that he used to work hard from sunrise to sunset just to find some food that he can eat. The society as whole was very poor. That was the general situation before the discovery of oil in the eastern part of the country in 1938 . The oil discovery has been a landmark and a critical point of renewal of the history of this new state (Al-Khateeb, 1998). This discovery helped the country transfer from being one of the poorest countries to being one of the richest countries in the world. 
Experts from Iraq, Egypt and other countries have been attracted to establishing the infrastructure of the country, including in the education and health sectors. In addition, the government has sent groups of students to study overseas (in Egypt, England, Italy, Turkey and Switzerland) to improve the quality of the country when they come back upon finishing their studies (Bukhari\& Denman, 2013).

Oil has become the main source of income for the country, which accounts more than 90 per cent of the kingdom (General Authority for Statistics, 2017). Therefore, the annual budget of the country was affected when the oil recession happened. Consequently, the government was unable to employ citizens. This situation has increased the unemployment rate among youths, especially with the strong desire of the private sector to attract non-Saudis from outside the country to work more and receive less pay (Ibn Sonaitan, 2008). In fact, the discovery of the oil changes the work culture in the country. Many people tend to work in trade or government sectors which are characterised by job security, high salaries, and annual bonuses for all employees and a flexible work system. Overall, Saudi people tend to live in an exaggerated luxury life. Compared to the situation of the country 30 years ago, Saudi is now more developed physically. This development, for instance, can be clearly seen from the fast growth in infrastructure and skyscrapers around the country.

\subsection{Social factors}

The population of the Kingdom of Saudi Arabia can be divided into two main groups. Firstly, the native people who are the members of Arab tribes who settled in the Arabian Peninsula thousands of years ago. This group is the largest and is prevalent in almost all regions of Saudi Arabia. The second group is called Hadhr (meaning civilise). These are Muslims from different nationalities who migrated a hundred years ago from their countries in East Asia, Turkey and other Arab countries for religious purposes in order to live in the two holy cities Mecca and Madinah. They are mostly concentrated in Mecca and Madinah and neighbouring cities such as Jeddah and Taif. The difference between the two groups is obvious; while the first group tend to be more stringent, especially toward their traditions and norms, the second group is more flexible and mostly educated. People can be easily identified by the names of their tribes and families since the third name (Surname) on their passport or national card refers to their tribes or family names, which involves thousands of people carrying the same names. Therefore, it is easy to identify the regions where these people originally come from based on their surnames. The importance of family as a social institution is obvious. Abu-Hilal (1986) describes the important role of the extended family in Arab culture in general and in Saudi culture in particular. He refers to a popular statement among Saudis saying, 'for the sake of family everything must be sacrificed' (p.76). Therefore, it is common that Saudis do not prefer to be separated or live far away from their families. For this reason, they try to have jobs which are close to their families. More than 50 years ago an American researcher described the role of family for Saudis by stating: The Arab is known by the family to which he belongs. However, great his talents, a man without family to back him is unlikely ever to count for much in the community. It is not surprising; then, the individual's loyalty and duty to his family are greater than any other social obligation. Since that time, the world has witnessed several changes within Saudi Arabia as a country, but the role of family remains the same.

The loyalty to the nuclear family or the extended family is then still strong. The nuclear family is normally assisting and contributing to the family members' decisions, including choosing husbands and wives for their family members. Moreover, they teach their children to behave in a good manner because they are not representing themselves alone; rather they represent the whole tribe and family. One of the great values is to help your tribes and extended family members as much as you can. Therefore, a person who does not help his relatives is considered an undesirable person in social gatherings and his people might not help him in the future when he needs help. This social connection leads to one of the big problems in Saudi Arabia known as 'wasta'which refers to using one's connections and/or influence to get things done, including in government transactions, such as for a quick renewal of a passport, waiving of traffic fines, and being hired for or promoted in a job.

\subsection{Educational factors}

Education is one of important factors that contributes to the movement and change of Saudi society and in the restructuring of its culture through the dissemination of information and knowledge and rehabilitation of its outputs to jobs and positions.

Compared to previous generations who did not have a good chance of education, in the last three decades or so the government has spread education to every city and village in the country. The government has provided free education for all people in Saudi Arabia, including the provision of free textbooks for all students. Moreover, in order to encourage Saudi youths to pursue undergraduate degrees, the government paid around SR 1000 or equal to a $\$ 400$ monthly stipend for students who are studying in many universities (Alamri, 2011). Although this tradition was practised in the past, when students were not willing to complete their bachelor's degrees, presently the government still pays it for all students, which uses up a huge part of universities' budgets. 
Bearing in mind also that the government strongly believes in educational investment by sponsoring qualified Saudi international students to study abroad and that they are expected to come back with new knowledge and skills to use in the government sector.

The influence of Islam on education in Saudi Arabia is obvious when analysing the educational policy of the country. The main objectives of education in Saudi Arabia are; to strengthen faith in God in Islam, and in Muhammad as Messenger of God and to emphasise that the life on earth is a stage of work and production during which a Muslim invests his/her abilities with full faith in eternal life in the other world. Moreover, education aims to teach that the messages of Muhammad ensure happiness for all humankind and rescue humanity from corruption and misery; and to provide educational resources and incorporate religious education as a basic element for all branches - primary, intermediate and secondary stages of education. Finally, education aims to maintain Islamic culture as a basic course in all years of higher education (Alhuqail, 2003). Consequently, there are five compulsory religious subjects in elementary, intermediate and secondary schools, including the Holy Quran, Tawhid (declaration of the oneness of God), Tajwid (recitation of Quran), Tafsir (interpretation, commentary of the Quran), Hadith (record of the sayings and doings of the prophet Muhammad - peace be upon him - and his companions), and Fiqh (Islamic jurisprudence) (Prokop, 2003). In addition, every school must have a Mosque (place for praying) and students must pray (Aldhur) at noon before leaving school to return to their homes. Moreover, there are special schools focusing on the teachings of the holy Quran called Quranic schools or memorisation of the holy Quran schools. The government encourages students to enrol in these schools by providing a special incentive and /or stipend for students who are willing to study in these schools. The number of Saudi public universities had increased from only three universities in 1970 to 24 at the end of 2009. As of the latter part of 2013, there were 25 public universities in Saudi Arabia (of which 16 were opened in the last decade, including Taif University, Al-baha University and the Saudi Electronic University) and nine private universities distributed all over the country. Approximately 80 per cent of faculty and staff were educated as international students, mostly in the U.S. and the U.K. (Sawahel, 2013). Therefore, it is legitimate to raise a question of what are the roles of these educated people in the changing the society? How do these roles have impact on the new generations? Ibn Sonaitan (2008) argued that although those returning from studying abroad usually take high positions in the country, they failed to supplement the national culture to benefit from the West in establishing sustainable development for the country. Rather, they establish consuming behaviours and practice Wasta to employ their family members and relatives. Alamri (2011) also agreed with the previous arguments. He further adds that it is a contradictory phenomenon in many Saudi universities, where most of the deans of schools have been educated internationally. However, bureaucracy is one of the main obstacles in higher education management in Saudi Arabia. In addition, there are many problems in Saudi Arabian education, such as the massively poor condition of school infrastructure, the large classes (approximately 35 students in one class), and high teaching burdens for teachers (Alamri, 2011). This situation has led to poor student academic performance, low quality of instruction and curricular challenges. In terms of this study, a Saudi international student studies mainly in 'religious education' before studying abroad. However, during studying abroad they are exposed to very different educational systems. This new education might influence them to some extent. Exploring the re-entry experiences though this study will show how Saudi returnees working in the academic arena re-adapt to their original system of education and how can they implement what they have already learnt from studying abroad.

\section{Conclusion}

This article summarised the whole, complex picture of Saudi culture and the traditions of Saudi culture in this globalised era. It showed how religious, political, economic, social and educational factors have formed some cultural dimensions of Saudi Arabia which do not function in other cultures. Some of the reasons behind these dimensions were justified.

\section{References}

Abu-Hilal, M. (1986). Foreign student's interaction, satisfaction, and attitudes toward certain aspects of the American culture: a case of Arab students in Southern California. (PhD thesis), University of California, Riverside.

Al-Abdulkaream, M. (2012). SahwatAltawheed (1st ed.). Beirut: Arabic company for research.

Alamri, M. (2011). Higher education in Saudi Arabia. Journal of Higher Education Theory and Practice, 11(4), 88-91.

Alarfaj, A. (2011). AlghuthaAlahwa (1st ed.). Beirut: Arabic cultural centre.

Albukhari, M. (2001). SaheehAlbukhari (1st ed.). Damascus: Dar TaougAlnajah.

Alhazmi, A. A. (2015). What it Looks Like to be in a Mixed Gender Society: the Essence of Transitioning Experience from Gender Segregated Environment to Mixed Gender Environment. Journal of Foreign Languages, 3(1), 4957.

Alhozaimi, N. (2011). Days with Johaiman (2nd ed.). Beirut: Arabic company for research. 
Alhuqail, S. (2003). Education policy in Saudi Arabia (3rd ed.). Riyadh: Alobaikan library.

Al-Khidr, A. (2011). Saudi Arabia biography of the state and society (2nd ed.). Beirut: Arab Network for Research and Publishing.

Alothaimeen, A. (1997). History of Saudi Arabia (1st ed.). Riyadh: Alobaikan library.

Al-Rasheed, M. (2010). A history of Saudi Arabia (2nd ed.). New York: Cambridge University Press.

Bukhari, F., \& Denman, B. (2013). Student scholarships in Saudi Arabia: Implications and opportunities for overseas engagement. In A. Abouammoh, L. Smith, \& SpringerLink. (Eds.), Higher education in Saudi Arabia achievements, challenges and opportunities (pp. 151-158). New York: Springer Netherlands.

Council of Senior Scholars, S. A. (2017). The original page. Retrieved from http://www.ssa.gov.sa/

Denman, B. D., \&Hilal, K. T. (2011). From barriers to bridges: an investigation on Saudi student mobility (2006-2009) International Review of Education, 57(3-4), 299-318

General Authority for Statistics, S. A. (2017). The original website. Retrieved from https://www.stats.gov.sa/

Ibn Sonaitan, M. (2008). Saudi Arabia Policy and tribes (1st ed.). Beirut: Arabic company for research.

Long, D. E. (2010). Culture and customs of Saudi Arabia. Westport, Conn: Greenwood Press.

Ministry of education, S. A. (2017). The original website. Retrieved from https://www.moe.gov.sa/en/Pages/default.aspx

Sawahel, W. (2013). Rapid progress in developing higher education. University World News, 270.

The Holy Quran, Q. (2010). The Holy Quran. Medina: King Fahad publication. 